\section{UC10: a new early Formosa papaya cultivar}

\section{Messias Gonzaga Pereira ${ }^{1 *}$, Lucas Nunes da Luz ${ }^{2}$, Renato} Santa-Catarina ${ }^{1}$, Helaine Christine Cancela Ramos ${ }^{1}$, Telma Nair Santana Pereira ${ }^{1}$, Gislanne de Brito Barros ${ }^{3}$, Geraldo Antônio Ferregueti ${ }^{4}$, Marcelo Vivas ${ }^{1}$, Diego Fernando Marmolejo Cortes $^{1}$, Julio Cesar Fiorio Vettorazzi ${ }^{1}$, Alinne Oliveira Nunes Azecedo ${ }^{1}$, Silvaldo Filipe da Silveira ${ }^{1}$, Jurandi Gonçalves de Oliveira $^{1}$ and Alexandre Pio Viana ${ }^{1}$

Abstract: UC1O is a new papaya cultivar, recommended to the southeast and northern regions of Brazil. It has a very good agronomic performance in and adaptation to these regions, with Formosa fruits of approximately $1.9 \mathrm{~kg}$ and yield of $260 \mathrm{t} \mathrm{ha}^{-1}$. The cultivar has early fruit production, and fruits have excellent flavor.

Keywords: Carica papaya L., plant breeding, hybrid, early production.

\section{INTRODUCTION}

Brazil stands out as one of the world's leading papaya (Carica papaya L.) producers, being India the first. In 2014, the Brazilian production of papaya was 1.60 million tons, corresponding to $12.7 \%$ of the world's papaya production, generating a total of U\$ 38.8 million (FAOSTAT 2017).

In that year, the largest Brazilian producers were the states of Bahia (368.875 tons) and Espírito Santo (311.150 tons). Together, they accounted for $65 \%$ of the Brazilian production, followed by the states of Ceará (115.525 tons), Rio Grande do Norte (86.342 tons), and Minas Gerais (43.556 tons) (IBGE 2019).

Despite the importance of papaya for the Brazilian agribusiness, all domestic production is concentrated primarily in the cultivation of four cultivars: 'Golden' and 'Sunrise Solo', from the Solo group, with small-fruit type (mean of $0.5 \mathrm{~kg}$ ); and the hybrids 'Tainung 01 ' and 'Calimosa', from the Formosa group, with higher yield when compared with the varieties (Pereira et al. 2015).

The continued growth of papaya crop depends, among other factors, on the availability of new cultivars that are productive in and adapted to a wide range of growing environments and specific cultivars for each segment of the national and international market.

This paper aimed to describe the main traits of the new papaya cultivar indicated to the southeast and northern regions of Brazil in order to increase its use and make it known to the scientific community.
Crop Breeding and Applied Biotechnology 19: 131-134, 2019 Brazilian Society of Plant Breeding. Printed in Brazil http://dx.doi.org/10.1590/198470332019v19n1c18

\footnotetext{
*Corresponding author: E-mail: messiasgpereira@gmail.com (D) ORCID: 0000-0002-3463-3768
}

Received: 18 April 2017 Accepted: 06 December 2017

${ }^{1}$ Universidade Estadual do Norte Fluminense Darcy Ribeiro, Av. Alberto Lamego, 2000, Parque Califórnia, s/n, 28.013-602, Campos dos Goytacazes, RJ, Brazil

${ }^{2}$ Universidade da Integração Internacional da Lusofonia Afro-Brasileira, Instituto de Desenvolvimento Rural, Avenida Abolição, Centro, 62.790-000, Redenção, CE, Brazil

${ }^{3}$ Universidade Federal do Piauí, Rua Cícero Eduardo, Bairro Junco, 64.600-000, Picos, PI, Brazil

${ }^{4}$ Caliman Agrícola S/A, Fazenda Santa Terezinha, BR 101, km 111, 29.900-000, Linhares, ES, Brazil 


\section{PEDIGREE AND BREEDING METHODOLOGY}

Cultivar UC10 was obtained from a biparental cross between the genotypes UCJS-12 (originally from CNPMFT) and UCSekati (originally from Malaysia) of the Formosa group (Cardoso et al. 2014). The genotypes used as parents were selected by the pedigree method (Figure 1) and belong to the germplasm bank of the papaya breeding program UENF/ Caliman (Pereira et al. 2015). The cross was carried out at Caliman Agrícola S/A, in Linhares, state of Espírito Santo (lat 19 23' 28" S, long 40 04' 20” W, and alt $33 \mathrm{~m}$ asl).

Cultivar UC10 was evaluated in two environments, Linhares (ES) and Pureza (RN), for two years (2012-2013). The experiment consisted of a completely randomized block design, with four replications and ten plants per plot, spaced at $3.6 \mathrm{~m} \times 1.5 \mathrm{~m}\left(5.4 \mathrm{~m}^{2}\right)$ apart. Field data were collected during the harvest performed at 270, 360, 450, and 540 days after planting in each location. The following variables

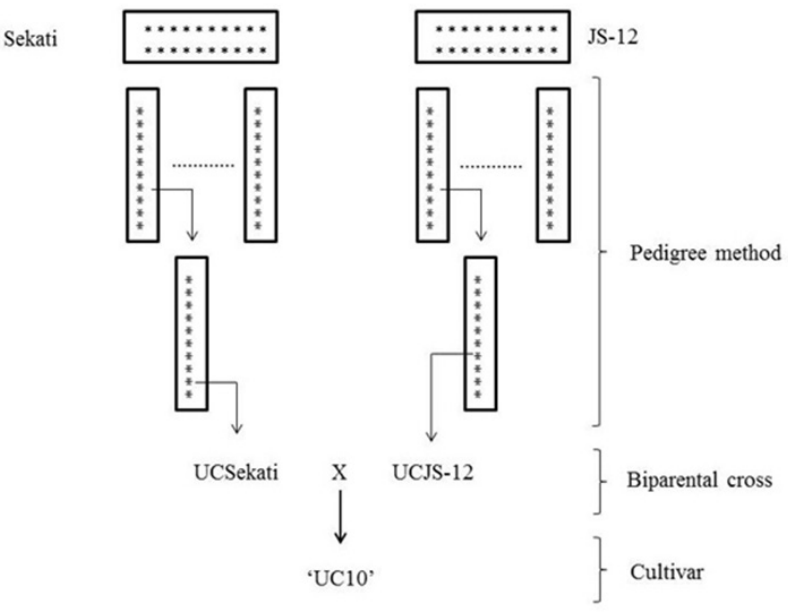

Figure 1. Pedigree of 'UC10' early papaya cultivar. were measured: fruit length - FL $(\mathrm{mm})$; fruit diameter - FD (mm); fruit weight - FW (kg); total soluble solids - TSS ( ${ }^{\circ}$ Brix); fruitless leaf axils - FLLA; Number of deformed fruits - NDF; Number of commercial fruits - NCF; Fruit yield - Yield $\left(\mathrm{t} \mathrm{ha}{ }^{-1}\right)$. Fruit yield was calculated by summing the number of commercial fruits in each season and environment, multiplying the result by the mean fruit weight in every season and environment, and converting to tons per hectare.

After data collection, fruits were subject to normality test (Kolmogorov-Smirnov) (Cruz et al. 2013) to check the consistency of the data to be evaluated by the analysis of variance in each season and cultivation environment. After the analysis per environment, the data were subject to the homogeneity test $F$ max, described by Ramalho et al. (2012), to compare the variance of the residuals. The analysis of variance and mean comparison of each trait was carried out using the $\mathrm{SAS}^{\circledR}$ University Edition.

\section{PERFORMANCE}

UC10 cultivar participated in the Value of Cultivation and Use trials - VCU from 2012 to 2013, being compared with 'Tainung 01', a reference cultivar (control). In these tests, the mean yield of 'UC10' was $260.01 \mathrm{t}$ ha'-1, and the mean yield of 'Tainung 01 ' was $185.75 \mathrm{t} \mathrm{ha}^{-1}$ (Table 1 ). When comparing the two cultivars, the relative yield of 'UC10' was $40 \%$ higher than the mean yield of 'Tainung 01'.

'UC10' reached higher sensory acceptance than 'Tainung 01', presenting higher means for the trait's aroma, flavor, texture, global impression, internal appearance, and external appearance. The purchase intention attributed by consumers of 'UC10' was higher than that of 'Tainung 01 '. The consumers attributed top scores to this cultivar for the categories purchase intent during the tasting and purchase intent in relation to fruit internal and external appearance (Table 2).

The observation of the frequency distribution of the score related to sensory variables is interpreted in terms of the acceptance area (score $\geq 6$ ) and rejection area (score $\leq 5)$ (Berilli et al. 2011, Viana et al. 2012). Despite presenting some traits outside the acceptance area, 'UC10' is situated within the acceptance range regarding the proper sensory

Table 1. Performance of 'UC10' and 'Tainung 01' papaya cultivars in four cropping seasons, in Pureza, RN, and Linhares, ES, Brazil

\begin{tabular}{|c|c|c|c|c|c|c|c|c|c|}
\hline \multirow{2}{*}{ Cultivar } & \multicolumn{4}{|c|}{ Pureza (RN) } & \multicolumn{4}{|c|}{ Linhares (ES) } & \multirow{2}{*}{$\begin{array}{c}\text { Average } \\
\text { Yield }\end{array}$} \\
\hline & TSS $^{1}$ & $\mathrm{NCF}^{2}$ & $\mathrm{FW}^{3}$ & Yield $^{4}$ & TSS & NCF & FW & Yield & \\
\hline 'UC10' & - & 80.5 & 1.952 & 292.39 & 9.8 & 61.12 & 1.919 & 227.64 & 260.01 \\
\hline 'Tainung 01' & - & 62.9 & 1.507 & 174.60 & 9.0 & 63.12 & 1.600 & 196.91 & 185.75 \\
\hline
\end{tabular}

${ }^{1} \mathrm{TSS}$ : total soluble solids content ( $\left.{ }^{\circ} \mathrm{Brix}\right) ;{ }^{2} \mathrm{NCF}$ : number of commercial fruits; ${ }^{3} \mathrm{FW}$ : fruit weight $(\mathrm{kg}) ;{ }^{4}$ Yield $\left(\mathrm{t} \mathrm{ha}{ }^{-1}\right)$. 
Table 2. Mean sensory acceptance and purchase intention of 'UC10' and 'Tainung 01 ' cultivars, attributed by consumers in 2014 , Campos dos Goytacazes, RJ, Brazil

\begin{tabular}{|c|c|c|c|c|c|c|c|c|c|}
\hline \multirow{2}{*}{ Cultivar } & \multicolumn{6}{|c|}{ Acceptance } & \multicolumn{3}{|c|}{ Purchase intent } \\
\hline & Aroma & Flavor & Texture & $\mathrm{GI}^{1}$ & $E^{2}{ }^{2}$ & $I A^{3}$ & $\mathrm{PI}^{4}$ & $\mathrm{PI} 2^{5}$ & $\mathrm{PI}^{6}$ \\
\hline 'UC10' & 6.24 & 6.99 & 7.08 & 6.76 & 6.20 & 7.16 & 4.04 & 3.36 & 3.92 \\
\hline 'Tainung 01' & 5.24 & 4.62 & 4.78 & 4.88 & 5.80 & 4.48 & 2.34 & 3.12 & 2.22 \\
\hline
\end{tabular}

${ }^{1} \mathrm{Gl}$ : global impression; ${ }^{2} \mathrm{EA}$ : external appearance; ${ }^{3} \mathrm{IA}$ : internal appearance; ${ }^{4} \mathrm{PI} 1$ : purchase intent evaluated during the tasting; ${ }^{5} \mathrm{PI}$ : purchase intent in relation to the external appearance; ${ }^{6} \mathrm{PI}$ : purchase intent in relation to the internal appearance.

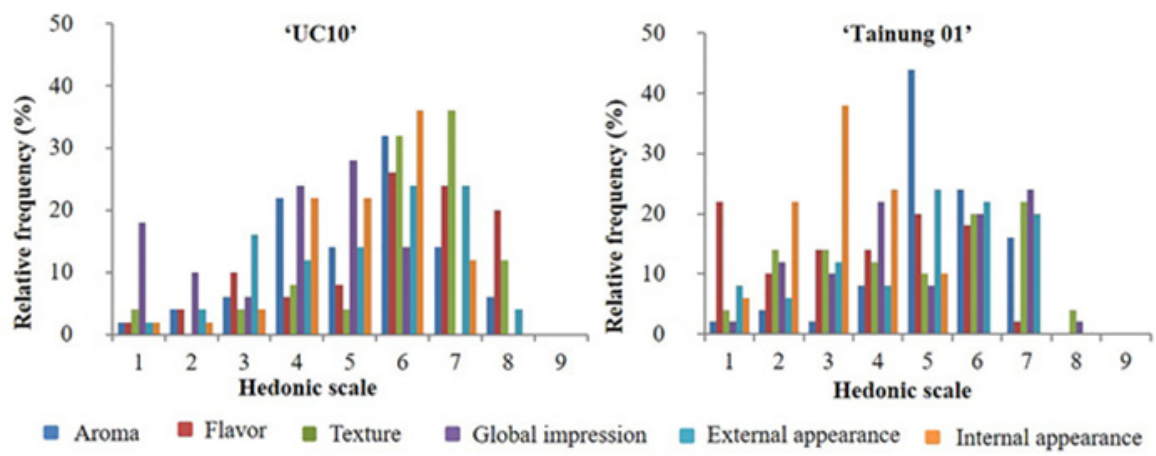

Figure 2. Frequency distribution of responses of consumers $(n=50)$, in $\%$, for acceptance of the sensory traits for the 'UC10' and 'Tainung 01' cultivars on a 9-point hedonic scale (1: dislike extremely; 2: dislike very much; 3: dislike moderately; 4: dislike slightly; 5: neither liked nor disliked; 6: like slightly; 7: like moderately; 8: liked very much; 9: liked extremely).

traits, such as taste, flavor, and global impression. 'Tainung 01 ' had most of the scores related to taste located in the rejection area, which did not occur with 'UC10' (Figure 2).

\section{OTHER CHARACTERISTICS}

'UC10' is an early fruit-production cultivar, with oblong, large fruits (mean of $1.9 \mathrm{~kg}$ ), and long petioles (about $5 \mathrm{~cm}$ ). The fruit presents dark green color when immature and light-yellow color when ripe, with slightly red pulp, and mean thickness of $3.5 \mathrm{~cm}$ (measured from the fruit peel to the central cavity), and small central cavity. The plant has reduced size, reaching up to $2.5 \mathrm{~m}$ of plant height and $0.5 \mathrm{~m}$ of insertion of the first fruits.

\section{SEED PRODUCTION AND DISTRIBUTION}

'UC10' was registered by the Ministry of Agriculture, Livestock and Supply - MAPA in 2014, under the registration number 32358. The seeds of this cultivar are produced in the seed production area of Caliman Agrícola S/A Company. The company is responsible for the production of hybrid seeds. Feltrin Seeds Company is responsible for seeds commercialization and distribution.

\section{REFERENCES}

Berilli SS, Almeida SA, Carvalho AJC, Freitas SJ, Berilli ACG and Santos PC (2011) Sensory evaluation of pineapple cultivars for Consumption in natura. Revista Brasileira de Fruticultura 33: 592-598.

Cardoso DL, Luz LN, Macêdo CMP, Gonçalves LSA and Pereira MG (2014) Heterosis in papaya: inter and intragroup analysis. Revista Brasileira de Fruticultura 36: 610-619.

Cruz CD, Regazzi AJ and Carneiro PCS (2013) Diversidade genética. In Cruz CD, Regazzi AJ and Carneiro PCS (eds) Modelos biométricos aplicados ao melhoramento Genético. UFV, Viçosa, p. 392-429.

FAOSTAT - Food and Agriculture Organization Corporate Statistical Database (2017) Available at: < http://faostat3.fao.org/browse/Q/ QC/E>. Acessed on Jan 16, 2017.

IBGE - Produção Agrícola Municipal (2017) Available at: < https://sidra. ibge.gov.br/tabela/1613>. Acessed on Jan 23, 2019.

Pereira MG, Ferreguetti GA, Pereira TNS, Ramos HCC, Cortes DFM, SantaCatarina R, Luz LN, Barros GBA, Arêdes FAS, Boechat MSB, Silveira SF and Oliveira JG (2015) Melhoramento genético do mamoeiro: 
programa Uenf/Caliman. In Martins DS (eds) Tecnologia de produção e mercado para o mamão brasileiro. Incaper, Vitória, p. 1-41.

Ramalho MAP, Ferreira DF and Oliveira AC (2012) Experimentação em genética e melhoramento de plantas. UFLA, Lavras, 303p.
SAS ${ }^{\circledR}$ University Edition - Statistical Analyses System - SAS/University Edition, (C) SAS Institute Inc.

Viana ES, Jesus JL, Reis RC, Fonseca MD and Sacramento CK (2012) Caracterização físico-química e sensorial de geleia de mamão com araçá-boi. Revista Brasileira de Fruticultura 34: 1154-1164. 